\title{
THE THEORY ON THE STATE OF THE CHOSŎN RULING ELITES: HOW DID THEY PERCEIVE THE RELATIONS BETWEEN THEMSELVES AND THE STATE?
}

\author{
Min Jung LEE, MA \\ Seoul National University \\ 1minj0510@naver.com
}

\begin{abstract}
This paper argues that it is necessary to analyze the identity of the ruling elite in the Chosŏn Dynasty through the nobles munbŏl 문벌(門閥) using the ideological methodology. The identity of the ruling elite in the Joseon Dynasty should be considered in relation to the state. In the first part of this paper, we review the existing studies on the relationship between the ruling elite and the state in Korea. The first group gives a view that the ruling class has autonomy from the state and has an identity outside the country. The second group of the studies shows that the ruling autonomous governments have encroached on the private sector. The third group are studies showing that the ruling class of the Chosonn Dynasty structurally could not escape the domination of the state. Each of these studies pointed out important points in characterizing the ruling elites of the Chosonn dynasty, yet they had some limitations because they lacked an ideological consideration of what their identity is fundamentally from. The second part of the paper presents how to overcome these limitations by insisting that the identity of the ruling class should be examined in relation to the state at that time through the issue of civilization.
\end{abstract}


Key words: ruling elite in the Chosŏn Dynasty, the nation, identity, nobles

조선 지배층의 국가론: 지배충과 국가와의 관계에 대한 논의를 중심으로

논문초록: 본 논문은 조선시대 지배엘리트의 정체성을 파악하기 위해서 는 문벌(門閥)이라는 소재를 통해 사상적인 방법론으로 분석하는 것이 필요함을 주장한 논문이다. 조선시대 지배엘리트의 정체성은 국가와의 관계 속에서 고찰되어야 한다. 이를 위해 우선 논문의 전반부에서 조선 의 지배엘리트와 국가의 관계에 대해 다룬 기존의 연구들을 세 가지 경 향으로 나누어 고찰하였다. 첫 번째 그룹은 지배층이 국가로부터 자율 성을 가지며, 국가 밖의 영역에 정체성을 두고 있다고 여기는 연구들이 다. 두 번째 그룹은 역시 국가로부터 자율성을 가지는 지배층이 사적 영 역으로 국가를 잠식하였다고 보는 연구들이다. 세 번째 그룹은 조선시 대 지배층은 구조적으로 국가의 지배를 벗어날 수 없었다고 여기는 연 구들이다. 각각의 연구들은 조선시대 지배엘리트의 성격을 파악하는 데 에 중요한 지점을 지적하였으나, 그들의 정체성이 근본적으로 무엇으로 부터 오는가에 대한 사상적 고찰을 결여했기 때문에 한계를 가진다. 논 문의 후반부에서는 이러한 한계를 극복하기 위한 제안으로, 문벌이라는 소재를 통해 당시 지배층의 정체성을 국가와의 관계 속에서 살펴보기를 주장하였다.

주제어: 조선시대 지배엘리트, 국가, 정체성, 문벌

\section{JAK WARSTWA RZĄDZĄCA W CHOSŎN POSTRZEGALA RELACJE MIĘDZY NIMI SAMYMI A PAŃSTWEM? PRÓBA UJĘCIA TEORETYCZNEGO}

Streszczenie: Autorka zakłada, że próba analizy warstwy rządzącej za czasów panowania dynastii Chosŏn na przykładzie szlachetnie urodzonych munbŏl 문벌 (門閥) powinna być przeprowadzana przy pomocy analizy ideologicznej, zaś tożsamość warstwy rządzącej należy rozpatrywać w relacji do kraju. Artykuł stanowi analizę istniejących badań, które dzielą się na trzy główne grupy. Pierwsza $\mathrm{z}$ grup wysuwa tezę, że warstwa rządząca jest niezależna od kraju i rządu i w takim oderwaniu należy rozpatrywać jej tożsamość. Druga grupa wskazuje na to, że warstwa rządząca opanowała również tzw. sektor prywatny. Trzecia grupa pokazuje, że warstwa ta nie była w stanie odciąć się strukturalnie od rządów. Dalsza część artykułu skupia się na analizie pozostałych punktów charakterystycznych dla koreańskiej warstwy rządzącej.

Słowa klucze: warstwa rządząca w Chosŏn, kraj, tożsamość, arystokracja. 


\section{Introduction: The Trend of Contemporary Scholarship on the Late Chosón's theory on the State}

The fact that the Late Chosŏn dynasty was ruled by powerful ruling elites called yangban has been generally accepted, and plentiful researchers have attempted to explain the nature of ruling elites, with the Late Chosón believing that the nature of ruling elites defines what Chosŏn state was. In detail, the interrelations between the ruling elites and the state can explain the structure of the political power relation, the degree of coercion power of the state, etc.

Numerous researchers have paid attention to the interrelations between the ruling elites and the state power and the bureaucracy to discover the character of Chosón state.As a consequence, they defined the ruling system of Chosŏn dynasty with concepts such as bureaucracy (이태진 1990; 박병련 1994; 정만조 2000), bureaucratic monarchy (James B. Palais 1998), centralized bureaucracy (이성무 1998; 남지대 1997), despotic monarchy (손병 규 2008: 서론) patrimonial bureaucracy (진덕규 2000) etc.

Other types of researches have examined the nature of Chosŏn's ruling system without direct consideration of bureaucracy, but rather through utilizing the concepts such as system ruled by sajok (士族支配體制) (김인걸 1988; 김현영 2000; 김성우 1999), factional politics (朋黨政治) (오수창 1985; 이태진 1987), public discourse politics (公論政治) (설석규 2002; 송웅섭 2011), NeoConfucian literati politics (土林政治) (이태진 1977; 최이돈 1994; 이 병휴 1997), impartiality politics (世道政治) (이선근 1975; 한국역사 연구회 1990), royal in- law politics (蕩平政治) (이태진 1993; 김성 윤 1997) as a way of understanding the representative ruling system of different period in the history of Chosonn dynasty. These studies are significant in that they reveal multi-faceted aspects of Chosonn's ruling system with substantial understanding of the political theory of NeoConfucianism which served as a ruling ideology of Chosón dynasty.

However, there remain some problems in both groups of scholarship. The former group is likely to overlook some important characteristics of the ruling system by simply applying socio-scientific concepts originated from historical experience of the West to Chosŏn's system without careful consideration. Although the latter group overcomes this limit, they are also flawed in that they arbitrarily defined the 'ideal type' of which Neo-Confucian politics could provide 
and applied experimental sources to this certain type, which led to mistaken assumption of development and fall of a certain political organization. Moreover, it seems even non-historical in a sense that the ideal type of the Neo-Confucian politics established by scholars reflects that they were overly conscious of the so-called 'modern values', such as liberalism and democracy that is concomitant of civil society (김영 민 2012; Cho 1997).

How, then, should we approach Chosŏn's theory on the state? First, I believe that examining the identity of the ruling agents is essential at this point. Attention should be given not only to the ruling ideology of Neo-Confucianism but also to the identity of the ruling elites who appropriated that ideological system. This does not indicate that Chosŏn's ruling elites blindly followed Neo-Confucian's ideal political system. In fact, the 'ideal type' provided 'theoretically' by a certain ideology or philosophy is modifiable in various contexts according to various agents who adopt those ideas. From this point of view, Neo-Confucian's political idea adopted by Chosŏn's ruling elites may also exist in various forms determined by the way they interpret and appropriate it. However, this does not indicate that they utilized Neo-Confucianism only in their own interests, since adopting a certain ideology means adjusting one's identity to that particular ideology. In a similar sense, Chosonn's ruling elites adjusted their behavior to the norms provided by Neo-Confucianism.

Second, analysis on how Chosŏn's ruling elites perceived the relationship between themselves and the state, is required. It is necessary to understand both a particular historical phenomenon, 'influential family (munbŏl, 門閥)', and the characteristics of Chosŏn's 'bureaucratic system', given that the two were closely related to each other. However, it should be noted that the focus of this paper is not on a simple explanation or reexamination of munborl of the late Chosón period and implicated relationship between the state and the ruling elites. Instead, this study attempts to explore the theory on the state of the Chosorn ruling elites; that is, how they perceived the relations between themselves and the state. This is possible by delving into the perception of the ruling elites of munbŏl. For those works mentioned above, I will seek some possible state-ruling elites relation types based on previous studies and suggest my own hypothesis on that relationship through examining ruling elites' perception on munbŏl. 


\section{Relationship between the State and the Ruling Elites in Chosŏn Dynasty}

Contemporary scholarship on the type of Chosonn's state-ruling elites' relationship could be largely classified into three. The first group of the studies suggests the type of ruling elites being outside the boundary of the state. From this point of view, the ruling elites are seen as those who acquired their own space, autonomous and independent from the state power, endeavored to achieve their ideology or interests, and eventually made their efforts paid off. Scholars taking this stance argue about the existence of the so-called civil society or an autonomous sphere corresponding to it in Chosŏn dynasty (김영민 2012; Duncan 2006). Rebutting a well-established 'prejudice' that the historical characteristic of the East Asia lies in despotism, with the monarch as the central figure (Wittfogel 1957), scholars of such studies attempted to prove there also existed a prototype of a modern civil society and democracy in the Korean history. These efforts were made especially in the field of political history, social history, and intellectual history.

The most representative study from this point of view emphasizes the rise of the rusticated literati (sarim, 士林) in the midcentury Chosŏn, who criticized social evils caused by meritorious elite (hungu, 勳舊) - a group adhered to the state showing aristocratic inclinations and went through a number of bloody purges (sahwa, 土 禍) and finally seized power becoming a principal agent of factional politics (이태진 1979; 김용흠 2004). Rusticated literati possessed ideological means of Neo-Confucianism, economic means of rural farms, institutional means of Confucian academy and community regulation, and political means of public discourse. Numerous studies argued that these various means served as significant sources or foundations for them to stay in an autonomous sphere away from the state. Studies stressing the rise of literati lineage (sajok, 土族) in the local society during the sixteenth to seventeenth century Chosorn and the confrontation between them and the central government (김성 우 2001; 한국역사연구회 2000), and studies on scholars of mountain and forest (sallim, 山林), who refused to become an official through state examination and maintained a certain distance from the king and central government (오수창 2003; 우인수 1999), share the common ground with studies on rusticated literati. Basically, 
widely-accepted research on political history of the late Chosŏn period, insists on an apparent existence of ruling elites who resisted the central government, which is believed to be possible through the resources they possessed.

However, these studies leave large room for criticism. Among all, it is largely proven that the rusticated literati and the meritorious elite came from the same political and social background (Wagner 1974; 이훈상 2002; 김범 2003). The fact that various resources mobilized by Chosŏn's ruling elites in order to check the state were by no means available without the help of the state has also been pointed out in many studies. The most representative example includes the issues of Confucian academies (Milan 1998). The biggest flaw is that such studies arbitrarily set up an ideal type of Neo-Confucianism, which served as a ruling ideology, and simply applied it to Chosŏn's history without careful consideration. According to these studies, NeoConfucianism is an ideology that provides political ideals, a formation of moral community in the autonomous local society. A claim that Neo-Confucianism greatly contributed to the formation of community based on the local volunteerism, namely localism (Peter 2003), is valid only when it is discussed within the context of the Chinse history. This view overlooks the fact that the form of the state the ruling elites of Chosonn envisioned was different from that of China, even though they accepted the same ideology. Consequently, there exists lack of reasons to argue that the ruling elites of Chosŏn was independent from the state (Steinberg 1997).

The second group of studies suggests the type of ruling elites exploiting the state for their own interests. There is a study that defines Chosǒn's ruling elites as 'aristocratic yangban-official', and suggests that they achieved 'bureaucratic centralization' using bureaucracy in order to protect their privileges (James 1998). According to this study, Chosorn was not a state where the ruling elites were subordinated due to the strong power of the state or a despotic monarch. Rather, the study argues that the ruling elites of Chosorn appropriated the resources of the state including bureaucracy to secure their interests exclusively. Thus, the power of the king was limited and was consistently in control by the ruling elites. Viewing Chosŏn's polity as 'bureaucratic monarchy' and not just a 'monarchy' also implies a restricted power of the king and the state.

Similarly to Palais, Martina Deuchler also pointed out the aristocratic tendency of yangban, and weakness of the state 
power (Martina 2003; 2015). She emphasized that the aristocratic nature of Korea's ruling elites was preserved since Silla (新羅)'s bone ranking system (Golpum jedo, 骨品制度), and therefore Chosŏn's yangban also enjoyed hereditary status based on descent and lineage. Although, gaining an office post through civil service, examinations were also necessary for them to maintain hereditary privilege, she puts more emphasis on 'Korea's Confucianization' since the seventeenth century Chosŏn, which allowed them to have alternatives other than entering an official life. The alternatives-maintained privileges by strengthening kinship system, practicing strict rituals, and living a life of scholarship while remaining in the countryside. According to this study, it was the society that affected the ruling elites more profoundly than the state, and, therefore, the ruling elites were able to use the state for their own sake.

These two studies have significant meaning in that they properly pointed out the hereditary privilege Chosón's ruling elites possessed. However, they also show limits by reconstructing history based on misunderstanding of Neo-Confucianism. Palais stressed that despite the egalitarian attribute of Neo-Confucianism, only the hierarchic and hereditary aspects were reinforced in order to protect the privilege of the ruling elites in Chosŏn. This seems to be a one-sided perspective, regarding ideology as used merely as a tool for certain interests or transformed by certain interests. Deuchler's study is meaningful in that it was an attempt to interpret the relationship between the state and the ruling elites, with the consideration of the identity and orientation of the ruling elites as the most significant variables. It is controversial, however, whether the ruling elites of the late Chosŏn period tried to establish their identity outside the boundary of the state, that is in the society. The argument that the ruling elites did not base their identity on the state needs more careful examinations.

The third type involves the ruling elites being subordinated to the state. Miyajima Hiroshi (宮嶋博史) defined Chosŏn as a state equipped with hierarchical and unitary bureaucratic system, which managed intensive rice farming (미야지마 히로시 2013) based on the theory of hydraulic irrigation-despotism presented by Karl A. Wittvogel. Therefore, the ruling elites of Chosŏn were not independent from the state since they had to rely on bureaucracy, contrary to the landlords of the West. The state-ruling elites' relationship, which was consolidated based on bureaucracy, coincided 
well with the Neo-Confucian political ideology that featured centralized bureaucratic ruling, upon which Chosŏn became 'NeoConfucianized' since the seventeenth century. Whether Chosón possessed infrastructure that could effectively manage and control social resources remains controversial. However, since Chosŏn's ruling elites were closely intertwined with the state through bureaucracy, Miyajima's argument that the ruling elites were entities not independent from the state with analysis of socioeconomic conditions proves crucial.

The ruling elites of Chosŏn showed heavy reliance on the state in every aspect including material foundation and establishment of identity, while by no means forming tense relations with the state. Chosonn's weak social differentiation is pointed out as the main cause of this phenomenon (Duncan 2000). The ruling elites within a highly aristocratic bureaucracy (or centralized aristocratic bureaucracy) sought to rely on the state's authority in order to acquire social resources, which turned out to be a favorable deal for the state as well in that it allowed them to compensate its weakness in resource control.

Among the three types of relationships between the state and the ruling elites I had mentioned above, the most reasonable type is, I believe, the last one. The ruling elites of Chosorn could not be independent from the state. Miyajima and Duncan's arguments reveal the circumstances in which there existed an inseparable connection between human beings who are bound by the material foundation and the state obligated to control societal resources. Although they mentioned Neo-Confucian ideology which stimulated changes in political and social spheres, this was adopted or applied only when it was mobilized for the needs of the state and the ruling elites or when socioeconomic conditions were properly developed. In this respect, these two studies are based on a firm stance that the material structure of the society determines human behavior and the course of history.

The questions to what extent Chosŏn's social differentiation progressed, how strong the infrastructural power was in controlling state resources, how successfully the bureaucratic ruling was carried out are not the focus of this study. Apparently, it is a meaningful process for historians to explore the level of Chosŏn's centralized power in comparison with that of modern nation or with other nations in the same period of time. More importantly, however, is to examine whether or not the ruling elites based their identity on the state and 
what they intended their relation with the state to look like. Ideology should not be considered as merely being appropriated as needed or passively waiting to be mobilized once the proper conditions appear. Inversely, certain ideology and values are likely to determine human behavior and trigger social transformation, which seems to be highly conspicuous in Chosŏn where ideological power was particularly influential. Considering the fact that Neo-Confucianism served as a ruling doctrine of the Chosón dynasty, the theory on the state of the ruling elites should be examined within this larger political ideology of Neo-Confucianism.

The orientation toward the state shown by the ruling elites of the late Chosón can be proved through a number of cases. The most representative case would be the unprecedented upsurge in state examinations during the period, which indicates that gaining an official post was of great importance to them. Obtaining official posts not only provided material foundations necessary for a living, but also a symbolic significance to their identities originating from the very fact that they became entitled to the official posts. There was still heavy pressure placed on the successful candidates since stable official life was not guaranteed even with the passing of the exams. Developing intimate relationships with influential people in the government was also an important task for them. A diary written by Hwang Yun-sŏk (黃乣錫), a scholar from a renowned family in Jeolla province during the reign of King Yŏngjo reveals how alert he was to situational circumstances and people in Seoul, which was his strategy to gain a government post. He even made a special request to the influential figures in the government for the sake of his father's advancement into the government (박현순 2013).

If the ruling class of the late Chosorn ultimately put their identity on the state and defined their relationship with it, the foremost subject that could demonstrate this would be munbŏl, more precisely, the perception by the ruling elites of munborl. The interesting thing is that the identity that underlies this perception was formed not in the late Chosonn period but in the early period within the framework of Neo-Confucian project. 


\section{Munbŏl and the Identity of Ruling Elites in Late Chosŏn}

Why munbŏl was chosen as my subject of concern needs some elaboration. This has to do with the definition of 'ruling elites'. The term 'ruling elites' in my paper is a concept that encompasses Chosonn's government official and a group of prospective officials. Specifically, it includes both officials already serving in the government and those preparing for the civil service examination while remaining in the local society or those who at least had self-awareness as the ruling elites despite their unstable living conditions almost compatible with the common people. The most important factor which determines the character of the ruling elites is their identity. As I conceptualized the ruling elites of Chosŏn as a group of people holding the identity of a ruler, they need to be examined within close relevance to the state's bureaucratic system.

The ruling elites of Chosŏn possessing the identity of a ruler had strong self-awareness as belonging to a particular lineage and being a descendent of a particular ancestor. It doesn't need to be explained further what significant kinship groups were in Chosŏn and China where Confucianism functioned as a dominant ideology. What's important is that there was an intimate connection between the two identities as a ruler and as a member of a particular lineage.

This, for example, is demonstrated in one's biographies and epitaphs etc. left by these individuals in which the mentioning of the protagonists' ancestors always comes ahead of the detailed description of the protagonist itself: the subjects related to the public posts (mainly in the government affairs) and achievements took up the most portion of the story that deals with the ancestors. The existence of the Law of Avoidance (sangp'ije, 相避制), which prohibited individuals who are in a certain range of kinship relations from working in the same department illustrates that the ruling elites of that time (이기명 2004) were highly conscious of close relationships between the kinship and public posts.

Becoming public officers involves a sequential process of school, education, and finally the civil service examination and each step cannot stand on its own in separation from the kinship group. At the stage of education, discipline within a family lineage was fortified as a way of preserving the tradition of family learning. A sudden increase in the establishment of academies related to certain 
family lineage (munjung sǒwŏn, 門中書院) during this time is an indication that the kinship system played a significant role in the process of education (이해준 2000). Let's take a look at the case of the civil service examinations. If we look into the Kukchopangmok (國朝榜目), which was a list of people who successfully passed the examination, the information on four ancestors (sajo, 四租), including, the father, grandfather, great-grandfather and maternal grandfather, and wife's father was an essential component in constituting the portion of personal information of the test takers (이연숙 2011). Even the sigwŏn (試券), a test paper of civil service examinations, required a birthplace of the candidates and the name of their ancestors to be recorded on it. This testifies that the ruling elite of Chosorn did not necessarily separate the identity as a ruler and as a member of a particular lineage (박현순 2012).

Munbŏl is production of the strong collaboration between the two identities, a state elite and a member of a particular lineage. The concept of munbŏl as commonly understood in contemporary scholarly trends is as follows; 'family lineage with a hereditary political and societal privilege through a constant nurturing of public officials', encompassing the concepts such as influential lineage (bŏlyŏl, 閥閱), lineage maintaining privilege for generations (kyomoksega, 喬木世家), families of renown lineage (myŏngmunsejok, 名門世族), successful lineage (sŏngbŏl, 盛閥) (차 장섭 1995). Hence, it was not the case that all kinship groups including munjung (門中) or chongjung (宗中) automatically turned into munbǒl. Rather, societal recognition of a particular lineage group as munbŏl took place only when descendants of an individual constantly obtained high ranking official posts and corresponding privileges that were equally compatible with those of their ancestor's. It is commonly believed that munborl was established after the reign of King Injo, that is, the late Chosŏn period (차장섭 1997). However, according to Lee Tae-jin's study, consciousness of 'renown lineage' (myŏngjok, 名族) was already formed in the early Chosŏn and it is rather dangerous to conclusively define the establishment period of munbŏl as the late Chosorn, considering that renown lineage consciousness is an embodiment of the self-pride of the ancestors who succeeded in the government and therefore could be considered as part of munbŏl discourse (이태진 1976).

I would like to especially pinpoint the perspectives of the academic circles that defined descent groups in Chosŏn 
as a private group (private sector) encroaching on the state (public sector). Researchers who have conducted their studies in political history of the late Chosón period have commonly shared the following views; munbŏl is a privileged power group, monopolizing public resources through a solid base achieved through marriage and official posts, which was then ultimately translated into royal clan politics (世 道政治), a pattern of succession of political authority by a particular lineage (진덕규 2011, 한국역사연구회 1990, 차장섭 1997, 오수창 1991). Especially, 'harmful effects of munbǒl' specified in various reform theories emerged in the late Chosonn period, served as a major evidence for the aforementioned views.

For example, discussing the corruption in political practice of Chosŏn period in the Usŏ (迂書), the author Yu Su-wǒn (柳壽垣), an official under King Yongjo made a reference to the munbŏl phenomena as a major cause in the failure of both the selection and utilization of talented individuals (김인규 2009). Practical learning scholar (實學者) Yi Ik (李瀷) also found the reason for ill functioning of the state's bureaucratic system in munbŏl (원재린 2006). In addition to these two cases, intellectuals of the time and the officials and the kings in the court have also pointed out the corruption and harmful effects of munbŏl. Researchers have shown a tendency of accepting these views of the Chosorn period indiscriminately, utilizing them as historical evidence.

However, there needs to be a clear distinction between munbŏl itself and harmful effects of munbŏl. If we carefully look into the arguments concerning the harmful effects of munborl made by the reformists of the late Chosŏn period, it can be referred that it is not the existence of munbŏl itself they found problematic, but rather harmful consequences resulting from the ill functioning of munbŏl. Hereditary privilege is the natural property of the ruling elites in the medieval period and this was secured institutionally at the state level. For example, the practice of taegache (代價制), a system of adding official rank to a kin group, was already codified into law during the Sejo reign in Chosŏn (최승희 1985). Emergence of munbŏl phenomena itself in Chosŏn wasn't a direct indication of social corruption. Rather, it is the point that the munborl phenomena begins to be perceived as harmful effects when the recognition arises that munbŏl disrupts the public order and security while violating the limits tolerated by the institution.

If the existence of munbŏl itself was perceived harmful 
and problematic, there arose various exceptional cases that are unexplainable. In 1823, a decision was presented allowing concubine's sons to enter office posts (許通), in which the following content was a part of it; "Our country has revered the dignity of a lineage when employing individuals, and not putting any distinction between concubine's sons, regarding them as a whole, seems careless. Therefore, they shall be differentiated according to their families. (我 國用人, 朁向門地, 謂之均是庶流無所分別, 非愐惜之意, 隨其家閥 以爲, 差等之地.)" This principle demonstrates that the state took for granted the practice of selecting officials based on munborl and institutionalized it. A similar case can also be found in the period preceding the so-called sedo, royal clan politics period. In addition, King Chŏngjo, who strove to construct a centralized bureaucratic government, explicitly emphasized lineage backgrounds as an important criteria in selecting the officials of the court library (kyujanggak, 奎章閣). There are numerous cases of this kind, yet understudied, due to the preoccupation of the researchers with the perception of viewing the existence of munbŏl itself as social corruption.

Kim Youngmin demonstrated that kinship groups can claim a legal justification as a political agent when they are placed within the ideology of Neo-Confucianism (김영민 2012a). If the suggestion that the ruling elites possessed the identity of Neo-Confucian scholars is accepted, then it can also be inferred that munbŏl phenomena in Chosŏn was not necessarily anti-state for people of the time. In this sense, previous views that defined munbŏl as a private group violating the public authority of the state and damaging public interests need to be revised. R. Bin Wong claimed that the role of the state and society were not differentiated and instead took the form of fractal in the case of China when compared to that of Europe: hence, the Chinese state could transfer a number of roles to the family lineage in local society while carrying out its minimal duties (Wong 1997). Although the state-society relationship was completely different in Chosonn from that of China, the relationship between the state and the lineage group was not hostile to each other, which was a case in China, and, moreover, they utilized their lineage as a base to enter central government posts. In order to demonstrate that the ruling elites of Chosonn ultimately based their identities on the state, their perceptions of munbŏl and of the operation of Chosŏn's bureaucratic system that institutionalized munbŏl need to be examined. 
Min Jung LEE: The Theory on The State of the Chosŏn Ruling...

\section{Conclusion}

Examining perceptions of Chosŏn's ruling elites on the relationship between themselves and the state corresponds with examining how the officials, statesmen, also referred to as state elites - perceived the existence of the state, or how the state should exist. In the end, this is about their state theory of the period concerned. In addition, this also enables us to delve into the character of Chosŏn's ruling system as well as the identity of the ruling elites defined by themselves within the framework of established relations between them and the state. This paper claims that the ruling elites drew their ultimate identities from the state and, in this sense, they held 'state-oriented' tendencies. This is found in their attempts to enter the government office through munbŏl. Chosŏn's ruling elites regarded descent groups as public realm within the ideology of Neo-Confucianism. Munbŏl, which has the symbolic power constructing the identity of Chosŏn's ruling elites also had the role of the nexus linking Chosŏn's ruling elites with their state Chosŏn.

\section{References}

Cha Jang-Seob 차장섭. 1995. “朝鮮後期 閥閱의 概念과 範疇 Joseon hugi Mun Yeol-ui gaenyeom-gwa beomju". 『조선사연구 Joseonsa yeongu』4.

Cha Jang-Seob 차장섭. 1997. 『朝鮮後期閥閲研究 Joseon hugi Mun-Yeol yeongu』. 서울: 일조각. Seoul: Iljogag.

Cho, Hein. 1997. The Historical Origin of Civil Society in Korea. Korea Journal 37:2.

Choi I-Deun 최이돈. 1994. 『朝鮮中期士林政治構造研究 Bughanui junggi salim jeongchi gujo 』. 서울: 일조각 Seoul: Iljogag. Choi Seung-Hoe 최승희. 1985. “朝鮮時代 兩班의 代加制 Joseon sidae yangban-ui daegaje”. 『진단학보 Jindan Hagbo』60.

Deuchler, Martina. 2015. Under the ancestors' eyes: kinship, status, and locality in premodern Korea. Cambridge: Harvard University Asia Center.

Deuchler, Martina. Lee Hung-Sang 이훈상 역. 2003. 『한국사회의 
유교적 변환 Hangug sahui-ui yugyojeog byeonhwan』. 서울: 아카넷 Seoul: Akanet.

Duncan, John. 2000. Origins of the Chosorn Dynasty. Seattle: University of Washington Press.

Duncan, John. 2006. The problematic modernity of Confucianism: the question of 'civil society' in Chosǒn Dynasty Korea. In Korean Society: Civil Society, Democracy and the State. Routledge.

Eisenstadt, S. N. 1958. Review of The Study of Oriental Despotisms as Systems of Total Power. The Journal of Asian Studies 17(3).

Eisenstadt, S. N. 1963. The Political System of Empires: The Rise and Fall of the Historical Bureaucratic Societies. The Free Press of Glencoe.

Fukuyama, Francis. 2011, The Origins of Political Order: From Prehuman Times to the French Revolution. New York: Farrar, Straus and Giroux.

Gorski, Philip. 2003. The Disciplinary Revolution: Calvinism and the Rise of the State in Early Modern Europe. Chicago: The University of Chicago Press.

Hangug Yeogsa Yeongu-Hui 한국역사연구회 편. 1990. 『조선정치사 Joseon Jeongchisa 1800-1863』上 Sang. 서울: 청년사 Seoul: Cheongnyeonsa.

Hangugsa Yeongu-Hui Joseon sigi sahuisa yeonguban 한국사연구회 조선시기 사회사 연구반 . 2000. 『조선은 지방을 어떻게 지배했는가 Joseon-eun jibang-eul eoddeotge jibaehaettneunga』. 서울: 아카넷 Seoul: Akanet.

Jeong Man-Jo 정만조. 2010. 『한국 역사상 관료제 운영시스템에 관한 연구 Hangug yeogsasang gwanryoje unyeong siseuteme gwanhan yeongu』. 서울: 국민대학교출판부 Seoul: Gugmin Daehaggyo Chulpanbu.

Jin Deog-Gyu 진덕규. 2000. 『한국정치사서설 Hangug Jeongchisaseoseol』. 서울: 지식산업사 Seoul: Jisig saneobsa. Jin Deog-Gyu 진덕규. 2011. “조선왕조 후기 지배세력의 세습적 유동성에 대한 연구 Joseon Wangjo hugi jibae sereyog-ui seseubjeog yudongseong-e daehan yeongu”. 『학술원논문집 인문 - 사회과학편 Hagsulweon nonmunjib inmunsahuigwahag pyeon』50(1).

Kim Beom 김범. 2003. "조선전기 ‘훈구·사림세력' 연구의 재검토” 
Min Jung LEE: The Theory on The State of the Chosŏn Ruling...

Joseonjeongi Hungu-Sarimseryeog yeongu-ui jaegeomto. 『한국사학보 Hangug Sahagbu』15.

Kim Hyeon-Yeong 김현영. 2000. "방법으로서의 지방사 -조선시기 ‘사족지배체제론'을 중심으로 Bangbeob-euroso-ui jibangsa - Joseonsigi 'Sajog jibaechejeron'-eul jungsim-euro". 『韓國地方史 研究의 現況과 課題Hangug Jibangsa Yeongu-ui hyeonhwang-gwa gwaje』. 서울: 韓國史研究會 Seoul: Hangugsa Yeongu-hui.

Kim In-Geol 김인걸. 1988. “조선후기 향촌사회 권력구조 변동에 대한 시론 Joseon hugi hyangchon sahui gwonryeog gujo byeongdong-e daehan siron”. 『韓國史論 Hangug-ui yeogsa』 19.

Kim In-Gyu 김인규. 2009. “柳壽垣의 職分主義 신분제 개혁론 ‘四民分業'과 ‘四民一致”를 중심으로 Ryu Suwon-ui jigbunjuui sinbunje gaehyeogron -'Saminbun-eob'-gwa 'Samin-ilchi'-reul jungsim-euro". 『동방학

Dongbanghag』 16.

Kim Seong-U 김성우. 1999. “17세기 전반 班常制의 확립과 土族支配構造의 정착 17-segi jeonban bansangje-ui hwaglibgwa sajogjibaegujoui jeongchag”. 『朝鮮史研究Joseonsa yeongu』8.

Kim Seong-U 김성우. 2001. 『조선 중기 국가와 사족 Joseon Junggi gugga-wa sajog』. 서울: 역사비평사 Seoul: Yeogsa Bipyeongsa.

Kim Seong-Yun 김성윤. 1997. 『조선후기 탕평정치 연구 Joseon hugi Tangpyeong jeongchi yeongu』. 지식산업사 Jisig saneobsa.

Kim Yeong-Min 김영민. 2012. "조선시대 시민사회론의 재검토 Joseon sidae simin sahuiron-ui jaegeomto”. 『한국정치연구 Hangug jeongchi yeongu』 21(3).

Kim Yeong-Min 김영민. 2012a. "친족집단의 정치적 정당성: 세도정치의 이념적 기초 해명을 위한 시론 Chinjog jibdanui jeongchijeog jeongdangseong: Sedo jeongchi-ui inyeomjeog gicho haemyeong-eul wihan siron". 『한국학논집 Hangughag-jib』 47.

Kim Yong-Heum 김용흠. 2004. “조선전기 훈구·사림의 갈등과 그 정치사상적 함의 Joseon jeongi hungu-sarim-ui galdeung- 
gwa geu jeongchi sasangjeog hamui”. 『동방학지 Dongbanghag-ji』 124.

Kim, Youngmin. 2012. Taking Historicity Seriously. Paper presented at Workshop on Korean and Comparative Political Philosophy. June 7-9.

Lee Byeong-Hyu 이병휴. 1999. 『朝鮮前期 士林派의 現實認識과 對應 Joseon jongi sarimpa-ui yeonji insig-gwa daeeung』. 서울: 일조각 Seoul: Iljogag.

Lee Gi-Myeong 이기명. 2004. “17世紀 土林政治의 政局動向과 相避制 運營”.『동국사학 Donggug sahag』 40.

Lee Hae-Jun 이해준. 2000. “朝鮮後期 門中書院의 概念과 性格 問題 Joseon hugi munjung seoweon-ui gaenyeom-gwa seonggyeog munje” 『韓國中世史論叢

李樹健敎授停年紀念- Hangug jungsesa nonchong - Lee SuGeon gyoso jeongnyeom ginyeom』. 경산: 논총간행위원회 Gyeongsan: Nonchonggan haengwiweonhui.

Lee Hun-Sang 이훈상. 2002. "에드워드 와그너의 조선시대 연구와 이를 둘러싼 논점들 Edeuweodeu Wageuneo-ui Joseon sidae yeongu-wa i-reul dulleossan sosnmunjib”. 『역사비평 Yeogsa bipyeong』59.

Lee Hyeon-jae 이영재. 2014. “조선시대 시민사회 논쟁의 비판적 재해석 Joseon sidae simin sahui sosjaeng-ui bipanjeog jaehaeseog”. 『정신문화연구 Jeongsin munhwa yeongu』 37(135).

Lee Seon-Geun 이선근. 1975 “勢道政治 Sedojeongchi”. 『한국사 Hangugsa』15. 서울: 국사편찬위원회 Seoul: Gugsapyeonchan wiweonhui.

Lee Seong-Mu 이성무. 1998. "조선시대의 왕권 Joseon sidae-ui Wanggweon”.『東洋 三國의 王權과 官僚制 Dongyang Samgug-ui Wanggweon-gwa gwanryoje』.서울: 국학자료원 Seoul: Gughag jaryoweon.

Lee Tae-Jin 이태진. 1976. “15世紀 後牛期의「鉅族」과 名族意識-「東國舆地勝覽」人物條의 分析을 통하여- 15segi hubangi-ui "geojog"-gwa myeongjog uisig - "Donggug yeoji seungram" inmuljo-ui bunseog-eul tonghayeo". 『한국사론 Hangugsaron』3.

Lee Tae-Jin 이태진. 1977. “土林과 書院 Sarim-gwa seoweon”. 
Min Jung LEE: The Theory on The State of the Chosŏn Ruling...

『한국사 Hangugsa』12. 서울: 국사편찬위원회 Seoul: Gugsapyeonchan wiweonhui.

Lee Tae-Jin 이태진. 1979. “16세기 士林의 歷史的 性格 16-segi sarim-ui yeogsajeog seongyeog”. 『大東文化研究

Daedongmunhwa yeongu』13.

Lee Tae-Jin 이태진. 1987. “黨派性論 批判 Dangpa seongron bipan” 『韓國史市民講座 Hangugsa simin gangjwa』1. 서울: 일조각 Seoul: Iljogag.

Lee Tae-Jin 이태진. 1990. “朝鮮王朝의 儒呚政治와 王權 Joseon Wangjo-ui yugyo jeongchi-wa wanggweon”. 『한국사론 Hangugsaron』23.

Lee Tae-Jin 이태진. 1993. “正租 -儒學的 계몽 절대군주- Jeongjo yuhagjeog gyeomong jeoldae gunju“. 『한국사 시민강좌 Hangugsa simin gangjwa』13. 서울: 일조각 Seoul: Iljogag.

Lee Yeong-Sug 이연숙. 2011. “조선시대 충청도 Joseon sidae chungcheong-do 『사마방목 Sama bangmog』 입록실태와 추이 Ibrog siltae-wa chui”. 『역사와 담론 Yeogsa-wa damron』58.

Mann, Michael. 1986. The Sources of Social Power 2. Cambridge University Press.

Milan G. Hejtmanek. 1998. “朝鮮中期 賜額書院을 둘러싼 君臣간의 갈등 Joseon Junggi Saaegseoweon-eul dullyeossan gunsingan-ui galdeung”.『東洋 三國의 王權과 官僚制 Dongyang Samgug-ui Wang Gweon-gwa gwanryuje』. 서울: 국학자료원 Seoul: Gughagjaryoweon.

Miyajima Hirosi 미야지마 히로시. 2013. 『나의 한국사 공부 한국사의 새로운 이해를 찾아서 Na-ui Hangugsa gongbu Hangugsa-ui saeroun ihae-reul chajaseo』. 서울: 너머북스 Seoul: Neomeobugseu.

Nam Ji-Dae 남지대. 1997. “執權官僚制論 Haengjeong gwanryo iron”. 『韓國史 認識과 歷史理論 Hangugsa insig-gwa yeogsa 서울 . 술 Seoul: 金容熇敎授停年紀念韓國史學論丵刊行委員會 KimYongSeob gyosu yeongnyeon-ginyeom Hangugsa hagron chonggan haenguiweonhoe.

O Su-chang 오수창. 1985. “仁祖代 政治勢力의 動向 Injo Dae jeongchi seryeog-ui donghyang”. 『韓國史學 Hangug 
sahag』13.

O Su-Chang 오수창. 1991. “세도정치를 다시 본다 Sedojeongchireul dasi bonda”. 『역사비평 Yeogsa bipyeong』 12.

O Su-Chang 오수창. 2003. "17세기 조선의 정치세력과 山林 17segi Joseon-ui jeongchi sereyog-gwa sallim". 『역사문화연구 Yeogsa munhwa yeongu』18.

Palais, James. 1975. Politics and Policy in Traditional Korea. Cambridge, Mass: Harvard Univ. Press.

Palais, James. 1975. Stability in Yi Dynasty Korea: Equilibrium Systems and Marginal Adjustment. Occasional Papers on Korea Vol. 3.

Palais, James. 1984. Confucianism and the Aristocratic/Bureaucratic Balance in Korea. Harvard Journal of Asiatic Studies 44(2).

Palais, James. 1998. “朝鮮王朝의 官僚的 君主制 Hangug Gunjuje, gwanryo juui gunjuje”『東洋 三國手 王權과 官僚制 Dongyang Samgug-ui Wang Gweon-gwa gwanryuje』. 서울: 국학자료원 Seoul: Gughagjaryoweon.

Park Byeonryeon 박병련. 1991. “朝鮮社會 兩班官僚制의 基本性格에 관한 試論 Joseon sahui yangbangwan gwanryoje-ui gibon seonggyeog-e gwanhan siron”. 『韓國의 社會와 文化 Hangug-ui sahui-wa munhwa』 16 .

Park Hyeon-Sun 박현순. 2013. “지방 지식인 黃乣錫과 京華士族의 교유 Jibang jisigin Hwang Yun-Seog-gwa gyeonghwa saju gyoyu". 『한국사연구 Hangugsa Yeongu』 163.

Park Hyeon-Sun 박현순. 2012. “조선후기 試券에 대한 고찰 試種別 試券의 특징을 중심으로- Joseon Hugi sigweon-e daehan gochal - Si Jong-Byeol sigweon-ui teugjing-eul jungsim-euro - “. 『고문서연구 Gumunseo yeongu』 41.

Peter, K. Bol. 2003. The Localist Turn and Local Identity in later Imperial China. Late Imperial China 24.

Reed, Bradly. 2000. Talons and Teeth: County Clerks and Runners in the Qing Dynasty. Stanford University Press.

Seol Seog-Gyu 설석규. 2002. 『조선시대 유생상소와 공론정치 Joseon sidae yusaengsangso-wa gongron jeongchi』. 서울: 선인 Seoul: Seonin.

Song Byeong-Gyu 손병규. 2008. 『조선왕조 재정시스템의 재발견-17 19세기 지방재정사연구 Joseon Wangjo jaejeongsiseutem-ui jaebalgyeon - 17-19-segi 
Min Jung LEE: The Theory on The State of the Chosŏn Ruling...

jibangjaejeongsa yeongu 』. 서울: 역사비평사 Seoul: Yeogsa bipyeongsa.

Song Eung-Seob 송웅섭. 2011. “조선 성종대 公論政治의 형성 Joseon Seong Jong-Dae gongron jeongchi-ui hyeongseong”. 서울대학교 국사학과 박사학위논문 Seoul Daehaggyo Gugsahaggwa bagsa hagwi nonmum.

Steinberg, David. 1997. Civil Society and Human Rights in Korea. Korea Journal 37. No.3.

U In-Su 우인수. 1999.『朝鮮後期 山林勢力研究 Joseon hugi sallim sereyog yeongu』. 서울: 일조각 Seoul: Iljogag.

Wagner, Edward W. 1955. The Literati Purges: Case Studies in the Factionalism of the Early Yi Dynasty. PhD Thesis, Harvard University.

Wagner, Edward W. 1974. The Ladder of Success in Yi Dynasty Korea. In Occasional Papers on Korea Vol. 1. Seattle: Univ. of Washington.

Wagner, Edward W. 1974. The Literati Purges: Political Conflict in Early Yi Korea. Cambridge, Mass: Harvard Univ. Press.

Weber, Max. 1958. Politics as a Vocation. [In] From Max Weber: Essays in Sociology. ed. H. H. Gerth and C. Wright Mills. New York: Oxford University Press.

Weon Jae-Rin 원재린. 2006 “星湖 李翼의 '造命'論과 신분제 개혁방안 Seonghu-iik-ui jomyeongron-gwa sinbunje gaehyeog bangan". 『실학사상연구 Sirhag sasang yeongu』29.

Wittfogel, Karl A. 1957. Oriental Despotism: A Comparative Study of Total Power. New Haven: Yale University Press.

Wong, R. Bin. 1997. China transformed: historical change and the limits of European. Ithaca: Cornell University Press.

Woodside, Alexander. 2006. Lost Modernities: China, Vietnam, Korea, and the Hazards of World History. Harvard University Press

Yu Bong-Hag 유봉학. 1991. “18.9세기 京·墽學界의 分岐와 京華士族 18.9 segi gyeong-hyanghaggye-ui bungi-wa gyeonghwa sajog”. 『국사관논총 Gugsa gwannonchong』 22 . 